\title{
Phylogenetic Relationships in Korean Elaeagnus L. Based on nrDNA ITS Sequences
}

\author{
OGyeong Son ${ }^{1}$, Chang Young Yoon ${ }^{2}$ and SeonJoo Park ${ }^{1 *}$ \\ ${ }^{1}$ Department of Life Science, Yeungnam University, Gyeongsan 712-749, Korea \\ ${ }^{2}$ Department of Biotechnology, Shingyeong University, Hwaseon 445-741, Korea
}

\begin{abstract}
Molecular phylogenetic analyses of Korean Elaeagnus L. were conducted using seven species, one variety, one forma and four outgroups to evaluate their relationships and phylogeny. The sequences of internal transcribed spacer regions in nuclear ribosomal DNA were employed to construct phylogenetic relationships using maximum parsimony (MP) and Bayesian analysis. Molecular phylogenetic analysis revealed that Korean Elaeagnus was a polyphyly. E. umbellata var. coreana formed a subclade with E. umbellata. Additionally, the genetic difference between E. submacrophylla and E. macrophylla was very low. Moreover, E. submacrophylla formed a branch from E. macrophylla, indicating that E. submacrophylla can be regarded as a variety. However, several populations of this species were not clustered as a single clade; therefore, further study should be conducted using other molecular markers. Although E. glabra f. oxyphylla was distinct in morphological characters of leaf shape with E. glabra. But E. glabra f. oxyphylla was formed one clade by molecular phylogenetic with E. glabra. Additionally, this study clearly demonstrated that E. pungens occurs in Korea, although it was previously reported near South Korea in Japan and China. According to the results of ITS regions analyses, it showed a resolution and to verify the relationship between interspecies of Korean Elaeagnus.
\end{abstract}

Key words - Elaeagnus, Elaeagnaceae, ITS, Molecular phylogeny

\section{Introduction}

Elaeagnus L. is a member of the family Elaeagnaceae with about 60 species distributed in Asia, Australia, southern Europe and North America (Heywood et al., 2007). The genus Elaeagnus is characterized by alternate leaves, most parts with silvery white or brown scales, tubular calyx, 4-lobed stamens equal in number and alternating with the sepals and fruit usually containing eight longitudinal ribs. According to the Angiosperm Phylogeny Group (APG) system, Elaeagnus belongs to the order Rosales, Eurosids. The initial taxonomic research on Elaeagnus L. was conducted by Linnaeus (1753), who established the genus, and Schlechtendal $(1857,1860)$ and Servettaz (1908), who conducted taxonomic research on all species of Elaeagnus L. in the world. Schlechtendal (1860) recognized 28 species in the genus and Servettaz (1908) reported 44 species through monographs. Servettaz also divided Elaeagnus L. into two sections, Sempervirentes of

*Corresponding author. E-mail : sjpark01@ynu.ac.kr evergreen group and Deciduae of deciduous group, which were supported by Zofu (1965) and Chang (1983). Britton and Brown (1913) designated Elaeagnus angustifolia as the type species of Elaeagnus L. Sun et al. (2010) eliminated the section name Deciduae by Art. 22.1 of the International Code of Nomenclature for algae, fungi and plants (ICN) (Melbourne Code) (McNeill et al., 2012) and used the autonym, Elaeagnus. To date, 60 species have been reported, including several species along with variants (Cronquist, 1981; Ohwi, 1984; Takhtajan, 1991; Lee, 1996).

Regarding Korean Elaeagnus L. was first conducted by Hemsley (1894), who recorded two species, E. macrophylla and E. umbellata, from the Korean peninsula. Since then, Elaeagnus L. has been reported by Palibin (1900), Servettaz (1909), Nakai (1911), Mori (1921), Nakai (1952) and Chang (1983). Meanwhile, Lee (1980) introduced six species and four varieties of Korean native species, and as well as one exotic species, E. multiflora, from Japan. Lee (1996) subsequently excluded E. umbrellata var. parvifolia and E. umbrellata var. longicarpa, and substituted them with E. glabra var. 
oxyphylla to E. glabra f. oxyphylla by recognizing seven species, one variety and one forma. Later, Lee (2007) changed this to six species and two varieties.

However, there are many problems in hybrid species. Previous studies have shown different results assuming putative parants of hybrids. For E. submacrophylla, it is a hybrid of $E$. pungens $\times$ E. macrophylla by Servettaz (1909), but it has been reported hybrids E. glabra $\times$ E. macrophylla in Korea by Lee (1996). In addition, E. maritima is divided in view that Ohwi (1984), Ohba (2003) and Lee (2007) regarded hybrid of species E. glabra $\times$ E. macrophylla, but Lee (1996) was referred to as intermediate type of head or hybrid species. Yoo et al. (1994) also investigated the distribution and characteristics of soil underlying the habitat of Korean Elaeagnus, while Ki (2004) conducted research on the Elaeagnus trichome, Koh (2005) conducted a taxonomic study, and Lee (2006) investigated the external morphology.

In the recent years, many studies have been undertaken on this plant, concentrating on it is agricultural and ornamental values. Fruits and other parts of the plant bodies are consumed for their nutritional values in Asia (Wang et al., 2006; Fu and Wang, 2007). Additionally, many species are commonly used in traditional medicine to treat symptoms such as cough, diarrhea, itching and foul sores. Phytochemical studies have shown various medicinal properties of this genus, including antioxidant and anti-tumor (Kim et al., 2007; Lee et al., 2011; Lee and Seo, 2011).

Despite the abundance of research on Elaeagnus L., there is still a need to record species with accuracy owing to the differing opinions among researchers regarding species and variety, and difficulty in identifying species caused by high variation within Korean taxonomic groups. In the present paper, the main objectives were to phylogenetic relationships among Korean Elaeagnus, to assess the amount of congruence between the inferred relationships and the existing classification. We used internal transcribed spacer (ITS) region of nuclear DNA because they have been phylogenetically useful in most groups of flowering plants at generic and infrageneric levels (Baldwin, 1992; Yoo and Park, 2012). The main objectives of this study include (1) construction of the phylogenetic relationship of Korean Elaeagnus based on ITS sequences; (2) testing the hypothesis of the hybrid origin in $E$. submacrophylla and E. maritima. This information should contribute to developing a reasonable classification system and to a better understanding of the evolution of Elaeagnus $L$.

\section{Materials and Methods}

\section{Plant materials}

All materials were collected from natural populations or specimens in the herbarium of Sung Kyun Kwan University (SKK; Korea) and the herbarium of the University of Texas (TEX; USA). Previous molecular phylogenetic analyses indicated sister clades from Hippophae and Shepherdia (Sun et al., 2002). Therefore, Hippophae rhamnoides subsp. yunnanensis, Hippophae rhamnoides subsp. wolongensis, Shepherdia argentea, and Shepherdia canadensis were selected as outgroups. All species samples were provided with voucher information and symbols (Table 1). In this study, We contained unrecorded species E. pungens, which was discovered in the Tongyeng, Gyeongsangnam-do (Unpublished).

\section{DNA extraction, PCR amplification and DNA sequencing}

Plant fresh leaves or herbarium specimens were used for isolation of genomic DNA. Total genomic DNA was extracted using the method described by Loockerman and Jansen (1996). For this study, the internal transcribed spacers form the nuclear ribosomal DAN (ITS) (White et al., 1990) was used. Genomic DNA samples were quantified using a UV-vis spectrophotometer (Geldoc-it ${ }^{\mathrm{TM}}$ imaging system, Upland, California, USA). PCR cocktail $(25 \mu \mathrm{l})$ consisted of $250 \mathrm{ng}$ genomic DNA, 1X Diastar ${ }^{\mathrm{TM}}$ Taq DNA buffer, $0.2 \mathrm{mM}$ of each dNTP, $10 \mathrm{pM}$ of each primer (ITS5, ITS4) and $0.025 \mathrm{U}$ of Diastar ${ }^{\text {TM }}$ Taq DNA Polymerase (SolGent Co., Korea). The ITS amplification conditions were as follows: initial denaturation at $95^{\circ} \mathrm{C}$ for $2 \mathrm{~min}$, followed by 35 cycles of $95^{\circ} \mathrm{C}$ for 20 sec, $56^{\circ} \mathrm{C}$ for $40 \mathrm{sec}$, and $72^{\circ} \mathrm{C}$ for $50 \mathrm{sec}$, with a final extension at $72^{\circ} \mathrm{C}$ for $5 \mathrm{~min}$, after which samples were held at $8^{\circ} \mathrm{C}$. Amplification of genomic DNA was conducted in a PTC-200 thermo cycler (Peltier Thermal Cycler, MJ Research, Waltham, MA, USA). PCR products were purified by using a Gel \& PCR purification system kit (Solgent Co., Korea) according to the manufacturer's protocols. Purified PCR products were sequenced with specific primers by an ABI (Applied Biosystems, 
Table 1. Taxa used in this study

\begin{tabular}{|c|c|c|c|c|}
\hline Taxon & Abbreviation & Collector / Voucher & Locality & $\begin{array}{l}\text { Accession } \\
\text { No. }\end{array}$ \\
\hline \multirow[t]{5}{*}{ E. umbellata Thunb. (보리수나무) } & EU04 & O. Son 2091010 (YNUH) & JejuIsland, Aewoleup & JQ062482 \\
\hline & EU07 & O. Son 2100604a (YNUH) & Gyongsangnam-do, Jinhaesi & JQ062483 \\
\hline & EU11 & O. Son 2100604b (YNUH) & Gyongsangbuk-do, Mt. Palgong & JQ062484 \\
\hline & EU20 & O. Son 2100614a (YNUH) & Gyongsangbuk-do, Jangsugun Janggyemyeon & JQ062485 \\
\hline & EU21 & O. Son 2100614b (YNUH) & Gyongsangbuk-do, Jangsugun Gyenammyeon & JQ062486 \\
\hline \multirow[t]{3}{*}{$\begin{array}{l}\text { E. umbellata var. coreana (H.Lév.) H.Lév. } \\
\text { (왕보리수나무) }\end{array}$} & EUC01 & S. Kim 2070519a (YNUH) & $\begin{array}{l}\text { Gyongsangbuk-do, Uljingun Bukmyeon Mt. } \\
\text { Eungbong }\end{array}$ & JQ062479 \\
\hline & EUC02 & H. Lee $2070519 b(\mathrm{YNUH})$ & $\begin{array}{l}\text { Gyongsangbuk-do, Uljingun Bukmyeon Mt. } \\
\text { Eungbong }\end{array}$ & JQ062480 \\
\hline & EUC03 & O. Son 2070519c (YNUH) & $\begin{array}{l}\text { Gyongsangbuk-do, Uljingun Bukmyeon Mt. } \\
\text { Eungbong }\end{array}$ & JQ062481 \\
\hline \multirow[t]{3}{*}{ E. multiflora Thunb. (뜰보리수) } & EMF01 & O. Son 2100604 (YNUH) & Gyongsangnam-do, Jinhaesi Ungdong & JQ062476 \\
\hline & EMF04 & O. Son $2100605(\mathrm{YNUH})$ & Gyongsangnam-do, Changwonsi Mt. Bulmo & JQ062477 \\
\hline & EMF07 & O. Son 2100605a (YNUH) & Gyongsangnam-do, Jinhaesi Dudong & JQ062478 \\
\hline \multirow[t]{3}{*}{ E. macrophylla Thunb. (보리밥나무) } & EMP05 & O. Son 2091024a (YNUH) & UlleungIsland, Ulleng-gun Ulleng-eup Dokdo & JQ062496 \\
\hline & EMP25 & O. Son 2101024c (YNUH) & Gyongsangnam-do, Geojesi & JQ062497 \\
\hline & EMP27 & O. Son 2090825 (YNUH) & UlleungIsland, Ulleng-gun Ulleng-eup Seomyeon & JQ062498 \\
\hline \multirow[t]{4}{*}{ E. submacrophylla Serv. (큰보리장나무) } & ESM01 & O. Son 2091010 (YNUH) & JejuIsland, Donnaeko & JQ062489 \\
\hline & ESM04 & O. Son 2091009 (YNUH) & JejuIsland, Sanyangri & JQ062491 \\
\hline & ESM10 & O. Son 2100219 (YNUH) & Jeollanam-do, Haenam Mt. Duryun & JQ062493 \\
\hline & ESM12 & O. Son 2100220 (YNUH) & Jeollanam-do, Haenam Songgilmyeon Songhwari & JQ062494 \\
\hline \multirow[t]{5}{*}{ E. glabra Thunb. (보리장나무) } & EG06 & J. Koh 050206 (SKK) & JejuIsland, Donnaeko & JQ062499 \\
\hline & EG07 & J. Kim 051031 (SKK) & JejuIsland, Donnaeko & JQ062500 \\
\hline & EG08 & O. Son 2100221a (YNUH) & Jeollanam-do, Wandogun & JQ062501 \\
\hline & EG09 & O. Son 2110221b (YNUH) & JejuIsland, yeondong & JQ062502 \\
\hline & EG10 & O. Son 2110221c (YNUH) & JejuIsland, yeondong & JQ062503 \\
\hline $\begin{array}{l}\text { E. glabra f. oxyphylla (Servett.) W.T.Lee } \\
\text { (좁은잎보리장나무) }\end{array}$ & EGO01 & J. Koh 050205 (SKK) & JejuIsland, Donnaeko & JQ062504 \\
\hline \multirow[t]{4}{*}{ E. maritima Koidz. (녹보리똥나무) } & EMT01 & O. Son 2100220a (YNUH) & Jeollanam-do, Bogillsland Bojilmyeon & JQ062504 \\
\hline & EMT02 & O. Son 2100220b (YNUH) & Jeollanam-do, Bogillsland Bojilmyeon & JQ062505 \\
\hline & EMT03 & J. Koh et al. 051023 (SKK) & $\begin{array}{l}\text { Jeollanam-do, Wandogun Gunoemyeon } \\
\text { Youngpungri }\end{array}$ & JQ062506 \\
\hline & EMT04 & H. Koh 050423 (SKK) & JejuIsland, Hangyeongmyeon Gotjawal & JQ062507 \\
\hline \multirow[t]{2}{*}{ E. pungens Thunb. } & EP01 & O. Son 2101018a (YNUH) & Gyongsangnam-do, Tongyeongsi Mt. Miruk & JQ062487 \\
\hline & EP02 & O. Son 2101018b (YNUH) & Gyongsangnam-do, Tohgyungsi Mt. Miruk & JQ062488 \\
\hline Shepherdia canadensis Nutt. & $\mathrm{SC}$ & $\begin{array}{l}\text { Merrill King and Robert M. } \\
\text { Gravey. } 13940 \text { (TEX) }\end{array}$ & Colorado, Larminer contry, USA. & JQ517290 \\
\hline Shepherdia argentea Nutt. & SA & Marian MacLord. 678 (TEX) & Colorado, Moffat contry, USA & JQ517289 \\
\hline $\begin{array}{l}\text { Hippophaë rhamnoides subsp. yunnanensis } \\
\text { Rousi }\end{array}$ & HRY & Sun et al. Y22 & Litang, Sichuan & AF440250 \\
\hline $\begin{array}{l}\text { Hippophae ramnoides subsp. wolongensis } \mathrm{Y} \text {. } \\
\text { S. Lian }\end{array}$ & HRW & Sun et al. W110 & Wenchuan, Sichuan & AF440252 \\
\hline
\end{tabular}

California, USA) 3730xl DNA analyzer by Solgent Co. (Daejeon, Korea).

\section{Data assembly and alignment}

The sequence fragments were assembled and aligned using Geneious pro v5.5 (Drummond et al,. 2011). Alignment gaps were treated as missing characters. PAUP $^{*}$ ver $4.0 \mathrm{~b} 10$ (Swofford, 2003) was used for parsimony analyses, which were conducted following widely used protocols for bootstrapping (Felsenstein, 1985). For the heuristic analyses, tree searches were performed with 1000 random sequence additions and tree bisection-reconnection (TBR) branch swapping. The 
consistency index (CI), retention index (RI) and rescaled consistency index (RC) were obtained by PAUP*. Bayesian inference (BI) analysis was conducted using MrBayse v3.2.1 (Ronquist and Huelsenbeck, 2003) with Markov chain Monte Carlo (MCMC) analyses of 500,000 generations for nuclear ribosomal DNA (nrDNA), and trees were sampled every 500 generations. Convergence of the MCMC was assessed by calculating the effective sample size (ESS) of the combined runs. All estimated parameters showed $>1,000$ significant of ESS. The first $25 \%$ of the generations were discarded as the burn-in. To estimate the posterior probability (PP) of recovered branches, $50 \%$ majority rule consensus trees were created.

\section{Results}

\section{Base sequence analysis and variation}

Total Genomic DNA was isolated from 34 individuals of 13 taxa and used as templates to amplify ITS base sequences. These amplified products were purified, then sequenced and identified, after which they were deposited in the GenBank database (Table 1). An arrangement of the ITS base sequence of 13 taxonomic groups and 34 individuals, including the outgroup, resulted in a total length of 645-650 bp without any significant difference. The base sequences arranged were 663 bp in total. The length of ITS 1 and 2 was 262-268 bp and 217$220 \mathrm{bp}$, respectively, and $5.8 \mathrm{~S}$ showed $16 \mathrm{bp}$ in all taxonomic groups. Overall, Shepherdia canadensis showed the shortest length of ITS (644 bp), while two species of the genus Hippophae showed the longest length of $650 \mathrm{bp}$. The lengths of ITS 1 (263 bp) and 2 (217 bp) in the in-group were the same, with the exception of E. umbellata EU04. A total of 542 bases among the 663 bp base sequence of arranged ITS showed no variations, while the remaining 136 bases varied. Among these, 97 taxonomically available characters were identified. The average base sequence composition of the whole group was $21.2 \% \mathrm{~A}, 23.8 \% \mathrm{~T}, 26.6 \% \mathrm{G}$, and $28.3 \% \mathrm{C}$. The G-C base composition determines the structure, and physical characters of DNA were shown to be $52.92 \%$ for ITS $1,51.81 \%$ for $5.8 \mathrm{~S}$, and $53.49 \%$ for ITS 2 . When base sequence variation including the outgroup was considered, two species in the genus Hippophae, E. glabra and E. glabra f. oxyphylla, showed $0-15.686 \%$. The base sequence variation in the in-group, E. multiflora, E. glabra and E. glabra f. oxyphylla, was $0-2.046 \%$. The in-group base sequence variation in each section showed similar results, with $0-1.094 \%$ being observed for the Sempervirentes section and $0-1.251 \%$ for the Elaeagnus section.

\section{Molecular phylogenetic study}

The Maximum Parsimony (MP) of Korean Elaeagnus L. based on the ITS revealed 14 parsimony trees containing 165 steps, with a consistency index (CI) of 0.909 , retention index (RI) of 0.945, and rescaled consistency index (RC) of 0.859 . MP tree analysis revealed that the in-group, Elaeagnus, showed more similarity to Shepherdia than to the other genera in the outgroup. It also formed a polyphylic group with a $100 \%$ bootstrap value that was divided into clade of $E$. pungens, section Sempervirentes and section Elaeagnus. E. multiflora, placing it in the deciduous section. Elaeagnus formed one distinct clade with a $98 \%$ bootstrap value. $E$. umbellata and E. umbellata var. coreana had a bootstrap value of $71 \%$, while E. umbellata var. coreana, which has ovatelanceolate leaves unlike $E$. umbellata, shared synapomorphy and formed a clade with a $62 \%$ bootstrap value. E. pungens of section Sempervirentes formed one clade with an $87 \%$ bootstrap value. Another section, Sempervirentes, formed a clade with a bootstrap value of less than $50 \%$. Clade of $E$. submacrophyllaE. macrophylla, which has silvery white scales on the back of the leaf, and clade of E. maritima - E. glabra - E. glabra f. oxyphylla which has brown scales on the back, fall into this category. E. macrophylla and E. submacrophylla formed clades with less than $50 \%$ bootstrap value, but $E$. submacrophylla showed a bootstrap value of $63 \%$. E. maritima, E. glabra, and E. glabra f. oxyphylla formed a clade with a bootstrap value of $61 \%$, but $E$. maritima formed a polytomy, rather than a clade. E. glabra formed two different clades with bootstrap values of $76 \%$ and $83 \%$ because of monophyletic collapse and was not separated from E. glabra f. oxyphylla since it has narrower leaves than E. glabra (Fig. 1).

Bayesian inference (BI) analysis revealed that E. pungens had a posterior probability (PP) of 0.55 , which was lower than the independent MP values and closer to the clade of section Elaeagnus, while creating one independent clade. The PP of section Elaeagnus was 0.98, while that of section Semper- 


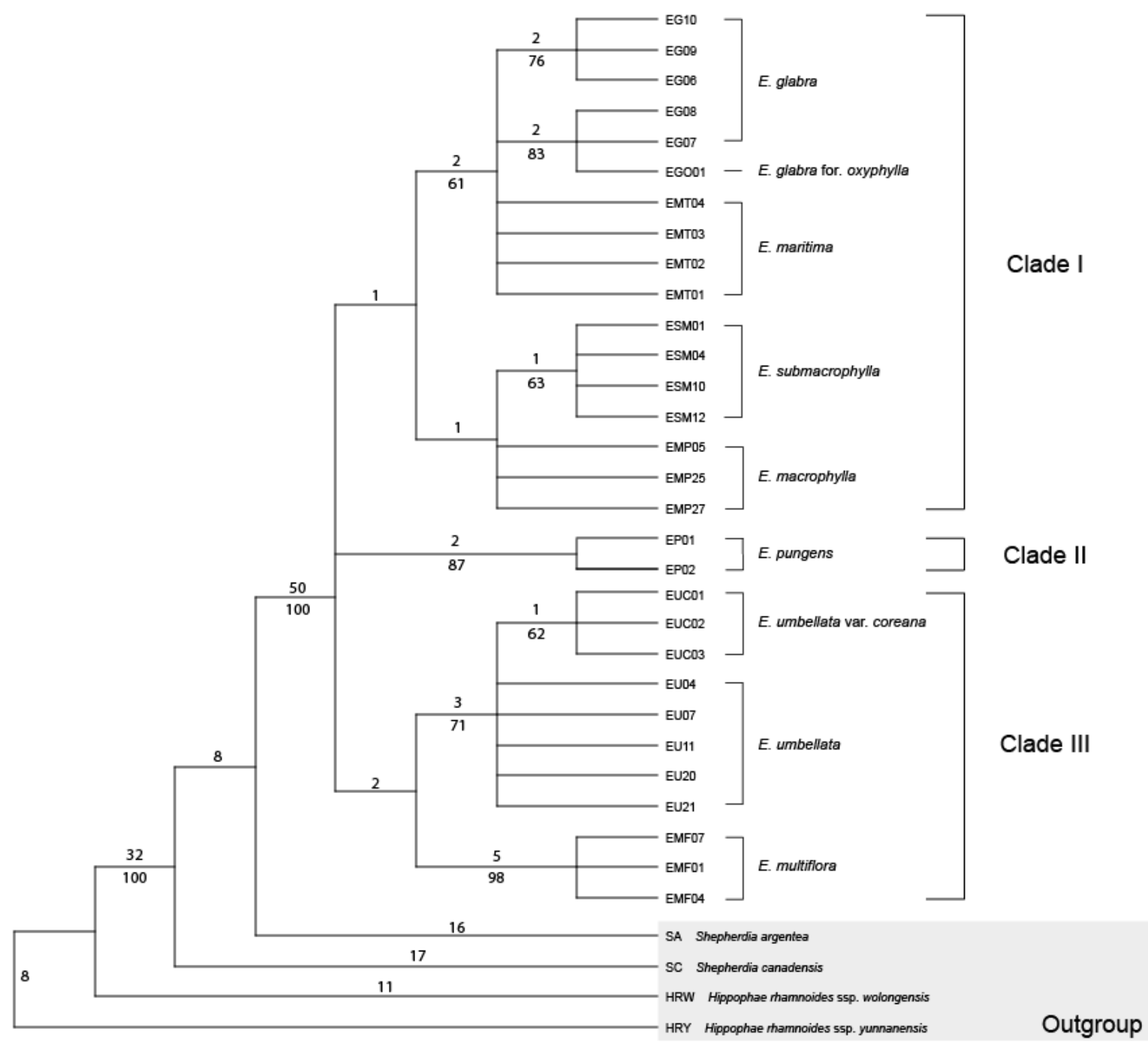

Fig. 1. Strict consensus tree (Length $=117, \mathrm{CI}=0.909, \mathrm{RI}=0.945$ ) based on 61 phylogenetically informative changes in ITS sequences of 34 taxa. The bootstrap values are found below branches and the number of changes is indicated above branches.

virentes was 0.6. E. multiflora, which belongs to section Elaeagnus, was located at the lowest level, with a PP of only 9.9 along with MP. Species belonging to section Sempervirentes showed the same result in MP. The E. submacrophylla - E. macrophylla clade had a PP of 0.91, while the clade had a PP of 0.81. E. glabra was shown to be a polyphyletic taxon (Fig. 2).

\section{Discussion}

Phylogenetic inference and elucidation of the evolutionary processes that generate biological diversity have been accomplished even at lower taxonomic levels using ITS of the nrDNA. In this study, a molecular phylogenetic study of
Korean Elaeagnus L. based on nrDNA ITS sequences was conducted and classification systems and relationships between taxonomic groups were analyzed. Our results indicate that both MP and BI tree showed the polyphyly of Elaeagnus species (Fig. 1, Fig. 2). MP tree was constructed tritomy: Clade I included E. glabra, E glabra f. oxyphylla, E. maritima, E. submacrophylla and E. macrophylla, Clade II was involved E. pungens and Clade III was comprised the remained taxa. Unlike MP tree, BI tree was divided into two major groups. Clade I consisting of E. glabra, E glabra f. oxyphylla, E. maritima, E. submacrophylla and E. macrophylla have a weak support posterior probabilities of 0.6 as a monophyletic group. Calde II consisting of E. pungens, E. umbellata, E. 


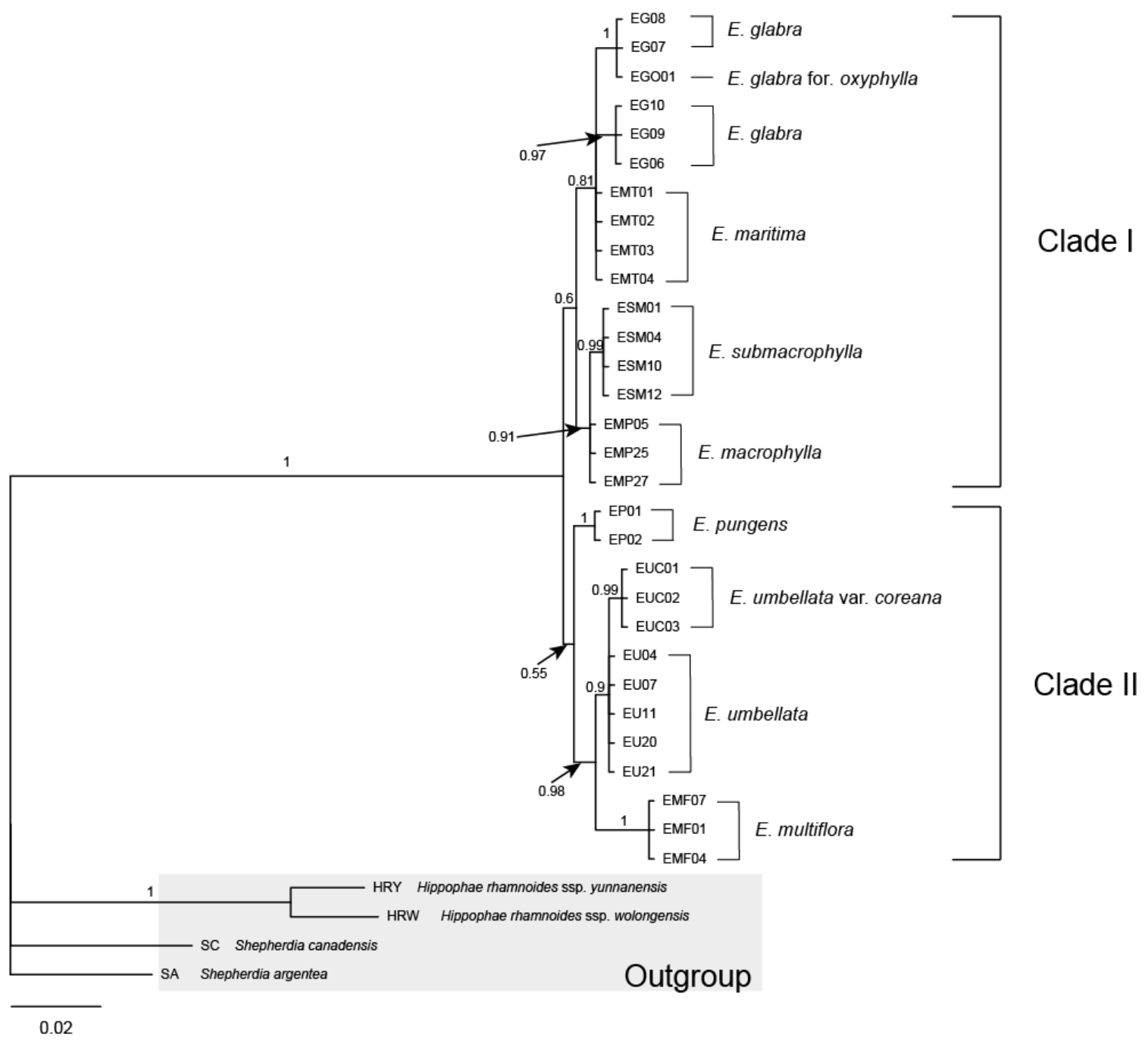

Fig. 2. Bayesian tree of ITS sequences of 34 taxa. Numbers above the branches are posterior probabilities $>0.5$.

umbellata var. coreana, and E. multiflora is monophyletic in phylogenetic analysis. However, results from ITS data are not concordant with morphological data Servettaz (1909). E. multiflora was an independent species as it formed a separate a clade with a bootstrap value of $98 \%$ and a posterior probabilities of 1 , without combining with other groups in the MP and BI tree based on nrDNA ITS sequences. Additionally, E. multiflora has a thorn and the earliest blooming time, as well as a fruit stalk that is longer than its flower stalk when the oval fruit ripens. Based on these evidence, E. multiflora has been classified as a distinct species. Sequence of $E$. umbellata var. coreana formed a subclade with those of E. umbellata with strong support posterior probabilities of 0.99 , but MP tree was found to have a relatively low bootstrap value (62\%).
The taxonomic opinion that E. umbellata var. coreana has been classified as a variety due to morphological differences in the leaves when compared to E. umbellata by Lee (1980). In the present study, the findings reported by Lee (1966) are tenable because it formed one independent clade by branching from the E. umbellata. Similarity. E. submacrophylla was sister to a clade of E. macrophylla, and monophyletic group. it is reasonable to consider E. submacrophylla a variation of E. macrophylla instead of a hybrid, since it reappeared in the clade of E. macrophylla, which has leaves that are oval or ovate. E. maritima calde showed that it formed a polytomy. Although it did form a clade with a relatively low bootstrap with E. glabra, it showed a discontinuity in form and molecular characteristics from E. macrophylla. Based on these results, it 
can be considered its own species. The most notable pattern in the ITS data is the phylogenetic position of E. pungens. E. pungens that is not previously been reported in Korea, was discovered from Tongyeong and Southern Gyungsang province of South Korea. In terms of growth period, it is reasonable to include E. pungens in section Sempervirentes. However, E. pungens formed an independent clade with strong support bootstrap value of $87 \%$ in the MP tree. By contract, in the BI tree, E. pungens was sister to a clade of section Elaeagnus (i.e., E. umbellata, E. umbellata var. coreana, E. multifloa) as a monophyletic group in clade II. It is necessary to include more maker. E. glabra, Both MP and BI trees, formed a clade with relatively high reliability and had polyphyletic group. This also showed different patterns from the external morphology and molecular phylogenetic study. These findings indicate that more methods are needed to evaluate organisms at the population level, and that such methods should consider interspecific hybrids, convergence and parallel evolution. In addition, the results are shown that the phylogenetic relationships between E. glabra and E. glabra f. oxyphylla are unresolved based on ITS sequence (Fig. 1, Fig. 2). E. glabra f. oxyphylla was recognized by morphological differences in leaves, that is, lanceolate-shaped leaves (Lee, 1996). On the basis of the ITS-derived phylogeny, E. glabra $\mathrm{f}$. oxyphylla was closely related to E. glabra (EG07, EG08). However, the phylogeny did not support monophyly of $E$. glabra f. oxyphylla, revealing no synapomorphic characters.

In conclusion, ITS phylogeny gives relatively high statistical support for the group of E. glabra-E. glabra f. oxyphylla clade, E. submacrophylla-E. macrophylla clade and E. umbellata-E. umbellata var. coreana clade in BI and MP tree. However, phylogenetic relationships among species of Elaeagnus revealed by ITS data are not consistent with the traditional inter-section classification system.

In general, molecular approaches have been more effective than morphological or cytogenetic ones in the identification of interspecific hybridization (Kaplan and Fehrer, 2007). DNA sequencing data, internal transcribed spacer (ITS) region of nuclear DNA, is a useful method in detection of hybrid and evolutionary trends of low-level taxa (Baldwin, 1992; Kim et al., 1994; Ainouche and Bayer, 1997; Sun et al., 2002). In the genus Korea Elaeagnus, hybrid origins of two species, E. submacrophylla and E. maritima have been suggested previously (Servattazd, 1908; Lee, 1980; Lee, 1996; Ohwi, 1984; Ohba, 2003; Lee, 2007). E. submarophylla have been classified separately from E. macrophylla due to its twig color and the form and texture of its leaves. For this reason, Servattaz (1908) considered it a variation E. pungens $\times$ E. macrophylla. Furthermore, Lee (1996) considered it a variation of E. glabra $\times$ E. macrophylla. ITS analysis have shown that E. glabra and E. pungens are not related, but $E$. macrophylla has topology of the E. submacrophylla. In addition, DNA evidence supported the hybrid species better than variety species. E. maritima is similar in appearance to E. glabra, but with more oblong and leathery leaves and reddish brown scales on the back of the leaves, which make the two species completely different. Ohwi (1984), Ohba (2003), and Lee (2007) described E. maritima as a hybrid of E. glabra $\times$ E. macrophylla, while Lee (1996) described it as a hybrid or intermediate form. However, a phylogenetic tree based on the nrDNA ITS region showed that it formed a polytomy. Although it did form a clade with a relatively low bootstrap with E. glabra, it showed a discontinuity in form and molecular characteristics from E. macrophylla. Based on ITS results, it can be considered its hybrid species. In order to confirm the putative parents, It need to be conducted additional research using plastid marker. And its implications in phylogeny will be discussed further study.

In the present study, ITS data of two putative hybrids did not cleary prove the relationship of each hybrids and their potential parents. Thus, Ongoing studies further base on the chloroplast genome to find out the potential maternal species of two hybrids because the plastid locus has generally been used to determine evolutionary relationships and genomic origin.

\section{Acknowledgment}

This research was supported by Yeungnam University research grants in 2013 and the research center for the policy suggestion of the Ministry of Educational Science (2014).

\section{References}

Ainouche, M.L. and R.J. Bayer. 1997. On the origins of the 
tetraploid Bromus species (section Bromus, Poaceae): insights from internal transcribed spacer sequences of nrDNA. Genome 40:730-743.

Baldwin, B.G. 1992. Phylogenetic utility of the internal transcribed spacers of nuclear ribosomal DNA in plants: An example from the Compositae. Mol. Phylogent Evol. 1:3-16.

Britton, N.L. and A. Brown. 1913. An Illustrated Flora of The Northern United States. Charles Scribner's Sons, New York, USA. 2:575.

Chang, C.Y. 1983. Elaeagnus L.: Flora Reipublicae Popularis Sinicae, Science Press, Beijing, China. 52:1-60.

Cronquist, A. 1981. An Intergrated System of Classification of Flowering Plants. Colurmbia Univ. Press. New York, USA. pp. 606-607.

Drummond, A.J., B. Ashton, S. Buston, M. Cheung, A. Cooper, C. Duran, M. Field, J. Heled, M. Kearse, R. Moir, S. Stones-Havas, S. Sturrock, T. Thierer and A. Wilson. 2011. Geneious v5.5, Available from http://www.geneious.com.

Felsenstein, J. 1985. Confidence limits on phylogenies: an approach using the bootstrap. Evolution 39(4):783-791.

Fu, Y.C and X.J. Wang. 2007. Advances on chemical constituents and pharmacological activities from plants of Elaeagnus L. Qilu Pharmaceutical Affairs 26:232-233.

Hemsley, W.B. and F.B. Forbes. 1894. An enumeration of all the plants known form China (Index Florae Sinensis). Jour. Linn. Sco. Bot. 26:1-592.

Heywood, V.H., R.K. Brummitt, A. Culham and O. Seberg. 2007. Flowering plant families of the world. Kew Publishing. London, UK. pp. 135-136.

Kaplan, Z and J. Fehrer. 2007. Molecular evidence for a natural primary triple hybrid on plants revealed from direct sequencing. Ann. Bot. 99:1213-1222.

Ki, K.R. 2004. Contribution of trichome morphology to the taxonomy of Korean Elaeagnus species. Department of Life Science, M.S. Thesis, Sungkyunkwan Univ., Korea (in Korean).

Kim S.A., S.I. Oh and M.S. Lee. 2007. Antioxidative and cytotoxic effects of solvents fractions from Elaeagnus multiflora. Korean J. Food Nutr. 20:134-142 (in Korean).

Kim, K.J. and R.K. Jansen. 1994. Comparisons of phylogenetic hypotheses among the different data sets in dwarf dadelion (krigia, Asteraceae): Additional information from internal transcribed spacer sequences of nuclear ribosomal DNA. Plant Syst. Evol. 190:157-185.

Koh, J.E. 2005. A taxonomic study of the Korean Elaeagnus
L.(Elaeagnaceae). Department of Life Science, M.S. Thesis, Sungkyunkwan Univ., Korea (in Korean).

Lee, C.H., J. Bae and J. Park. 2011. Pharmacognostical studies on the Korean folk medicien 'BoRiSuNaMu'. Kor. J. Pharmacogn. 42:1-5 (in Korean).

Lee, D.B. 2006. Taxonomic Study on the Genus Elaeagnus in Korea. Department of Life Science, M.S Thesis, Hannam Univ., Korea (in Korean).

Lee, J.H. and W. Seo. 2011. Determination of phytochemical contents and biological activities from the fruits of Elaeagnus multiflora. J. Food Sci Nutr. 16:29-36

Lee, S.T. 2007. Elaeagnus: In Park, C.W. (ed.), The Genera of Vascular Plants of Korea, Flora of Korea Editorial Committee, Seoul, Korea (in Korean).

Lee, T.B. 1980. Illustrated Flora of Korea. Hyangmunsa, Publishing Co., Seoul, Korea. pp. 561-562 (in Korean).

Lee, W.T. 1996. Lineamenta Florae Koreae. Academy Publishing Co., Seoul, Korea. pp. 713-716 (in Korean).

Linnaeus, C. 1753. Species Plantarum. p. 121.

Loockerman, D.J. and R.K. Jansen. 1996. The use of herbarium material for DNA studies: In Stussey, T.J. and S. Sohmer (eds.), Sampling the Green World, Columbia Univ. Press, New York, USA. pp. 205-220.

Mcneill, J., F.R. Rarrie, W.R. Buck, V. Demoulin, W. Greuter, D.L. Hawksworth, P.S. Herendeen, S. Knapp, K. Marhold, J. Prado, W.F. Prudhomme Van Reine, G.F. Smith and J.H. Wiersema. 2012. International Code of Botanical Nemenclature for Algae, Fungi and Plant (Melbourne Code). A. R. G. Gantner Verlag, Rugell, Liechtenstein. pp. 57-58.

Mori, T. 1921. An Enumertion of Plants Hitherto Known from Corea. Gov. Chos. pp. 259-260.

Nakai, T. 1911. Elaeagnus. Flora Koreana. Vol. II. J. Coll. Sci. Imp. Univ. Tokyo, Japan. 31:178-179.

. 1916. Elaeagnus Japoniae, Coreae et Formosae. Bot. Mag. Tokyo, Japan. 30:72-76.

1952. Elaeagnus. In A Synoptical Sketch of Korean Flora. Bull. Natl. Sci. Mus. Tokyo, Japan. pp. 31-75.

Ohba, H. 2003. Flora of Japan. Vol. IIc. Kodansha. Tokyo, Japan. pp. 152-158.

Ohwi, J. 1984. Elaeagnus. In Flora off Japan. Smithsonian Institution. Washington, USA. pp. 646-648.

Palibin, J. 1900. Conspectus florae. Pars. secunda. trudy Imo. S. -Peterburgsk. Bot. Sada. 18:186-187.

Ronquist, F., Huelsenbeck. 2003. MrBayes3: Bayesian phylogenetic inference under mixed models. Bioinformatics 
19:1572-1574

Schlechtendal DFL. 1857. Elaeagnaceae. Prodromus Systematis Naturalis Regni Vegetabilis 14:606-616. . 1860. Elaeagnacearum in Candollei prodromo (Vol. XIV) expositarum adumbrates. Linnaea 30:304-386.

Servettaz, C. 1908. Note preliminaire sur la Systematique des Elaeagnacees, Bull. de l'Herb. Boiss. 2. serie Tome VIII. pp. 381-394.

1909. Monographie des Elaeagnacees in Beihefte Botanischen Centralbatt 25:1-128.

Sun, M. and Q. Lin. 2010. A revision of Elaeagnus L. (Elaeagnaceae) in mainland China. J. Syst. Evol. 48:356-390. Sun, X. Chen, R. Ma, C. Li, Q. Wang and S. Ge. 2002. Molecular phylogenetics of Hippophae L.(Elaeagnaceae) based on the internal transcribed spacer (ITS) sequences of
nrDNA. Plant Syst. Evol. 235:121-134.

Swofford, D.L. 2003. PAUP*: Phylogenetic Analysis Using Parsimony (*andothermethods). Version.4. Sinauer Associates, Sunderland, Massachusetts, USA.

Wang, Y., P. Zhao, Y. Wang and Y. Zhang. 2006. Nutritional composition of wild Elaeagnus angustifolia fruits. Journal of Gansu Agricultural Univ. China. 41:6-28.

White, T.J., T. Birns, S. Lee and J. Taylor. 1990. Amplification and direct sequencing of fungal ribosomal RNA genes for phylogenetics: In Gelfand, D., J. Sninsky and T. White (eds.), PCR Protocols: A guide to methods and applications. Academic Press, San Diego, USA. pp. 315-322.

Yoo K.P. and S.J. Park. 2012. A phlogenetic study of Korean Carpesium L. based on nrDNA ITS sequences. J. Korean Plant Res. 25:96-104 (in Korean).

(Received 26 August 2014 ; Revised 22 October 2014 ; Accepted 12 November 2014) 